\title{
Thermodynamic Modeling of Oxidation of Tin Nanoparticles
}

\author{
Jindřich Leitner ${ }^{1} \cdot$ David Sedmidubskýn
}

Submitted: 23 July 2018/in revised form: 27 September 2018/Published online: 19 October 2018

(C) ASM International 2018

\begin{abstract}
A thorough thermodynamic analysis of oxidation of tin nanoparticles was performed. Solid tin oxides $\mathrm{SnO}_{2}, \mathrm{Sn}_{3} \mathrm{O}_{4}$ and $\mathrm{SnO}$ were considered according to the bulk phase diagram and a number of experimental results on tin nanostructures oxidation were taken into account in the assessment. Two equilibrium models with different spatial configuration, namely two single-component particles and core-shell model were explored. The surface energies for solid $\mathrm{SnO}$ and $\mathrm{Sn}_{3} \mathrm{O}_{4}$ were obtained on the basis of DFT calculations while the interfacial energies at $\mathrm{SnO}_{2}(\mathrm{~s}) / \mathrm{Sn}(\mathrm{l})$ and $\mathrm{Sn}_{3} \mathrm{O}_{4}(\mathrm{~s}) / \mathrm{Sn}(\mathrm{l})$ interfaces were assessed using a broken bond approximation. The opposite influence of nanosizing on stability of $\mathrm{SnO}_{2}$ and $\mathrm{SnO} / \mathrm{Sn}_{3} \mathrm{O}_{4}$ oxides is demonstrated. It is due to the surface contribution which is higher for $\mathrm{SnO}_{2}$ (s) than $\mathrm{Sn}(\mathrm{l})$ while lower for $\mathrm{SnO}(\mathrm{s})$ and $\mathrm{Sn}_{3} \mathrm{O}_{4}(\mathrm{~s})$ compared to $\mathrm{Sn}(\mathrm{l})$. This situation can explain some experimental findings during oxidation of $\mathrm{Sn}$ nanoparticles, namely an increased stability of $\mathrm{SnO}(\mathrm{s})$ and $\mathrm{Sn}_{3} \mathrm{O}_{4}$ (s) with respect to both liquid tin and solid tin dioxide.
\end{abstract}

This invited article is part of a special issue of the Journal of Phase Equilibria and Diffusion in honor of Prof. Jan Vrestal's 80th birthday. This special issue was organized by Prof. Andrew Watson, Coventry University, and Dr. Ales Kroupa, Institute of Physics of Materials.

Jindřich Leitner

leitnerj@vscht.cz

1 Department of Solid State Engineering, University of Chemistry and Technology, Prague, Czech Republic

2 Department of Inorganic Chemistry, University of Chemistry and Technology, Prague, Czech Republic
Keywords surface energy $\cdot$ thermodynamic modeling $\cdot$ tin nanoparticles $\cdot$ tin oxides

\section{Introduction}

Oxidation of metal nanostructures is one of size/shape dependent phenomena which are intensively studied now. A huge number of experimental works as well as theoretical studies on this subject have been published recently. Equilibrium thermodynamics provides very useful tools for studying various size/shape effects in the top-down approach. ${ }^{[1-3]}$ Whereas the effect of particle size and surface energy on the melting point has been studied both by experimental methods and theoretical modeling for many systems, the phase transitions in partly open systems involving exchange of one or more components with surrounding atmosphere have been less explored. Within the family of metal-oxide systems, Navrotsky et al. ${ }^{[4-6]}$ have calculated phase equilibria in the systems Co- $\mathrm{CoO}_{x}-\mathrm{O}_{2}(\mathrm{~g})$, $\mathrm{Fe}-\mathrm{FeO}_{x}-\mathrm{O}_{2}(\mathrm{~g})$ and $\mathrm{Mn}-\mathrm{MnO}_{x}-\mathrm{O}_{2}(\mathrm{~g})$ for bulk and nanoparticles forms and have shown substantial influence of nanosizing on stability of various oxide phases. The aim of the present paper is to carry out a similar analysis for the system $\mathrm{Sn}-\mathrm{SnO}_{x}-\mathrm{O}_{2}(\mathrm{~g})$.

\section{Thermodynamic Description of the bulk Sn-O System}

A thorough thermodynamic analysis of the Sn-O system including an assessment of thermodynamic data for tin oxides has been performed by Cahen et al. ${ }^{[7]}$ It should be noted, however, that substantial differences between the optimized and experimental values of entropy at $298.15 \mathrm{~K}$ 
exist for $\mathrm{SnO}_{2}$ and $\mathrm{Sn}_{3} \mathrm{O}_{4}$ oxides. The assessed value $S_{\mathrm{m}, 298}\left(\mathrm{SnO}_{2}\right)=73.23 \mathrm{~J} \mathrm{~K}^{-1} \mathrm{~mol}^{-1}$ is 1.4-times higher than the experimental value $51.82 \mathrm{~J} \mathrm{~K}^{-1} \mathrm{~mol}^{-1}$ obtained from low-temperature heat capacity measurements. ${ }^{[8]} \mathrm{A}$ possible reason for this discrepancy may lie in a variable oxygen stoichiometry of $\mathrm{SnO}_{2}$ (oxygen vacancy formation yielding a sub-stoichiometric $\mathrm{SnO}_{2-\delta}$ ) that may stabilize this phase towards higher temperatures and/or lower partial pressures of oxygen. In fact, the $\mathrm{Sn}_{3} \mathrm{O}_{4}$ phase can be considered as oxygen deficient $\mathrm{SnO}_{2-\delta}$ with rutile structure and one-third of oxygen vacancies cumulated in (011) planes in an ordered pattern. ${ }^{[9]}$ Based on the assessed data $^{[7]}$ the Sn-O phase diagram was calculated using the FactSage software ${ }^{[10]}$ as shown in Fig. 1. Three invariant points can be identified in the temperature range 300-800 K under the conditions summarized in Table 1.

Tin sesquioxide $\mathrm{Sn}_{2} \mathrm{O}_{3}$ has been identified as a product of bulk $\mathrm{SnO}$ disproportionation reaction ${ }^{[11,12]}$ as well as a product of nano-Sn oxidation. ${ }^{[13]}$ Being an intermediate oxide between $\mathrm{SnO}$ and $\mathrm{SnO}_{2}$, its stability has been examined on the basis of first-principle calculations. ${ }^{[14,15]}$ Nevertheless, $\mathrm{Sn}_{2} \mathrm{O}_{3}$ was not included into the present calculations due to absence of complete thermodynamic data.

\section{Oxidation of Nano-Sn}

Oxidation of nano-Sn as well as the stability of nano- $\mathrm{SnO}_{2}$ have been subjects of many studies. Although some intermediate oxides, namely $\mathrm{SnO}, \mathrm{Sn}_{3} \mathrm{O}_{4}$ and $\mathrm{Sn}_{2} \mathrm{O}_{3}$, have been observed during oxidation, the most stable oxide, $\mathrm{SnO}_{2}$, has been obtained in most cases and the resulting particles frequently adopted a core $(\mathrm{Sn})-\operatorname{shell}\left(\mathrm{SnO}_{2}\right)$ structure.

Using XRD and HRTEM Huh et al. ${ }^{[16]}$ have observed oxide formation on a surface of almost spherical tin nanoparticles with an average diameter $28 \mathrm{~nm}$. Oxidic shells were composed of $\mathrm{SnO}_{2}$ which was amorphous at low temperatures while it crystallized in tetragonal rutile structure after heating above $500 \mathrm{~K}$. A metastable (highpressure) orthorhombic form of $\mathrm{SnO}_{2}$ has been also observed. In their subsequent study ${ }^{[13]}$ they have observed the tin particles oxidation (6-40 $\mathrm{nm}$ in diameter) in air which resulted in an oxide shell composed of $\mathrm{SnO}$ and $\mathrm{Sn}_{2} \mathrm{O}_{3}$ oxides. Using a simultaneous TG/DSC technique combined with XRD characterization of product oxides Song and Wen ${ }^{[17]}$ have investigated the oxidation of tin (nano)particles with average diameter $110 \mathrm{~nm}$ in air. Their results reveal a two-stage oxidation process. During a continuous heating $\left(2-20 \mathrm{~K} \mathrm{~min}^{-1}\right) \mathrm{SnO}$ shell is created first at temperatures $473-523 \mathrm{~K}$. The second step in the temperature range $673-973 \mathrm{~K}$ results in a formation of

Table 1 Invariant points in the Sn-O system calculated with data from $^{\text {[7] }}$

\begin{tabular}{lcc}
\hline Coexisting phases & $T(\mathrm{~K})$ & $p\left(\mathrm{O}_{2}\right) / p^{\circ}$ \\
\hline $\mathrm{SnO}(\mathrm{s})-\mathrm{Sn}_{3} \mathrm{O}_{4}(\mathrm{~s})-\mathrm{SnO}_{2}(\mathrm{~s})$ & 410.0 & $2.2 \times 10^{-65}$ \\
$\mathrm{Sn}(\mathrm{l})-\mathrm{SnO}_{(\mathrm{s})-\mathrm{Sn}_{3} \mathrm{O}_{4}(\mathrm{~s})}$ & 545.3 & $6.3 \times 10^{-47}$ \\
$\mathrm{Sn}(\mathrm{l})-\mathrm{Sn}_{3} \mathrm{O}_{4}(\mathrm{~s})-\mathrm{SnO}_{2}(\mathrm{~s})$ & 714.5 & $1.6 \times 10^{-33}$ \\
\hline
\end{tabular}

Fig. 1 Phase diagram of the system $\mathrm{Sn}-\mathrm{O}$ calculated with data from Ref 7

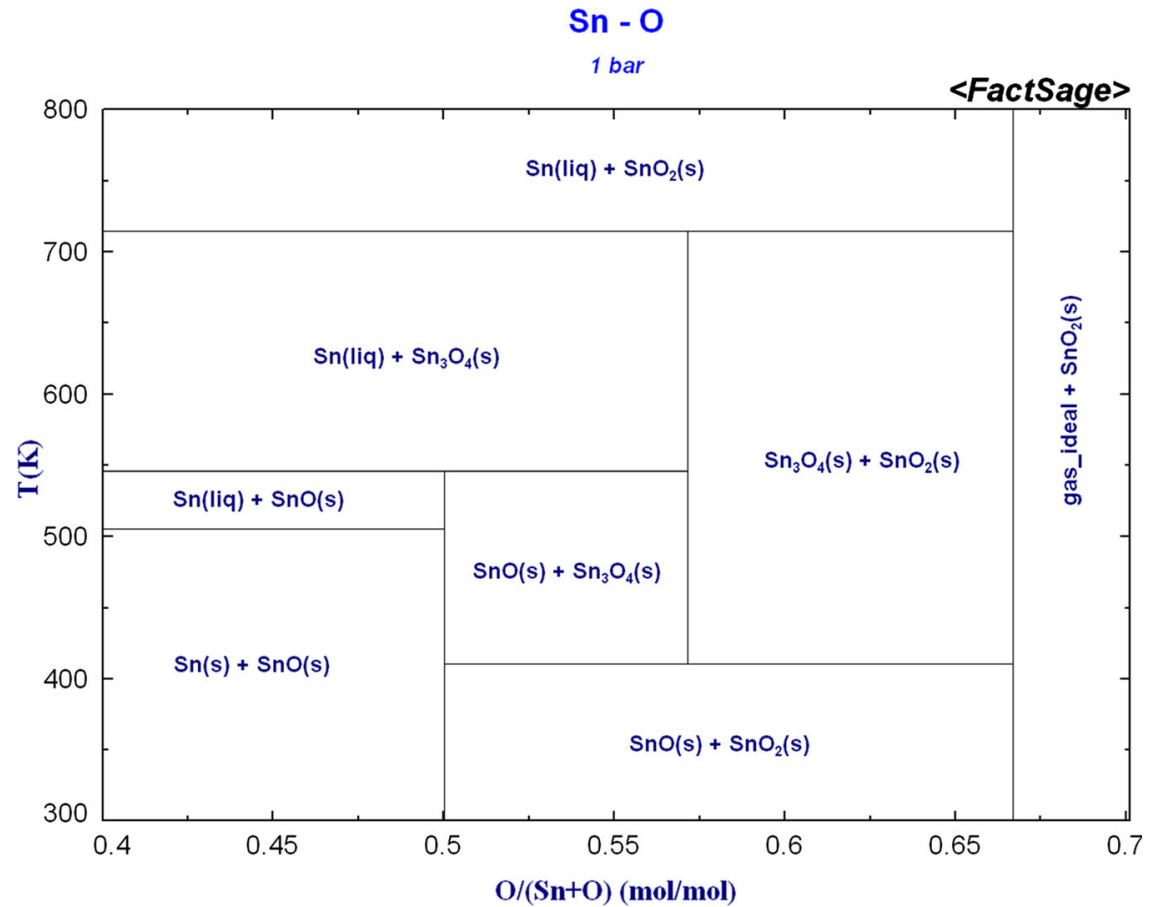


$\mathrm{SnO}_{2}$ coexisting with $\mathrm{SnO}$. At temperatures above $1073 \mathrm{~K}$, only $\mathrm{SnO}_{2}$ is present in the oxidic shell of particles. These results have been also confirmed under isothermal heating at various temperatures in the range $473-1173 \mathrm{~K}$ for $4 \mathrm{~h}$. A similar sequence of oxidation products $(\mathrm{Sn} \rightarrow$ $\mathrm{SnO}+\mathrm{SnO}_{2} \rightarrow \mathrm{SnO}_{2}$ ) has been also observed in the case of tin nanowires. ${ }^{[18]} \mathrm{Sn}_{3} \mathrm{O}_{4}$ as a product of liquid tin nanodroplets oxidation was identified by Mima et al. ${ }^{[19]}$ who employed TEM for an in situ analysis of $\mathrm{Sn}(1) / \mathrm{tin}$ oxide boundary during oxidation. Sutter et al. ${ }^{[20]}$ have studied the size-dependent room temperature oxidation of tin nanoparticles in air. $\mathrm{SnO}$ has been identified as an oxidation product and using TEM images of core/shell particles with various sizes (3-100 $\mathrm{nm}$ in diameter) the dependence of $\mathrm{SnO}$ shell thickness on particle diameter has been found out. It should be noted that the oxidation of tin nanoparticles is influenced by a lowering of tin melting temperature which has been observed experimentally. ${ }^{[21,22]}$ This decrease in temperature can be also calculated using the Gibbs-Thomson equation or the Pawlow equation. ${ }^{[23]}$ Using the data from Table 2 one can calculate a decrease as low as $60 \mathrm{~K}$ for nanoparticles with a diameter of $5 \mathrm{~nm}$.

\section{Thermodynamic Modeling of Nano-Sn Oxidation}

Equilibrium relations in nanosystems are fundamentally dependent on topology of the system under consideration, e.g. on spatial configuration of coexisting phases. In the following analysis we consider two different configurations, namely (1) two single-component particles (analogy to the Pawlow equation for the melting point decrease) and (2) core-shell geometry, which are both applied on the $\mathrm{Sn}(\mathrm{l})-\mathrm{SnO}_{2}$ (s) and $\mathrm{Sn}(\mathrm{l})-\mathrm{Sn}_{3} \mathrm{O}_{4}$ (s) equilibrium. According to the proposed classification scheme ${ }^{[29]}$ the respective configurations represent models of the first and the second generation. Although core-shell model is physically more realistic, simpler two particles model is often used for the thermodynamic modeling of equilibria in oxide systems as well as for evaluation of structural stability of polymorphic oxide nanoparticles. ${ }^{[4-6,30-32]}$

\subsection{Single-Component Particles}

The spatial configuration of such a system is shown in Fig. 2. The equilibrium condition for the reaction $\mathrm{Sn}(\mathrm{l})+\mathrm{O}_{2}(\mathrm{~g})=\mathrm{SnO}_{2}(\mathrm{~s})$ is in detail derived in "Appendix" (Eq 23, 26 and 27) yielding Eq 1 with the respective bulk and surface contribution given in Eq 2 and 3:

$$
\begin{aligned}
& \Delta_{\mathrm{r}} G^{\mathrm{np}}\left(T, p_{\left(\mathrm{O}_{2}\right), \mathrm{np}}\right)=\Delta_{\mathrm{r}} G^{\text {bulk }}\left(T, p_{\left(\mathrm{O}_{2}\right), \mathrm{np}}\right) \\
& +\Delta_{\mathrm{r}} G^{\text {surf }}\left(T, p_{\left(\mathrm{O}_{2}\right), \mathrm{np}}\right) \\
& =0 \\
& \Delta_{\mathrm{r}} G^{\text {bulk }}\left(T, p_{\left(\mathrm{O}_{2}\right), \mathrm{np}}\right)=\Delta_{\mathrm{r}} G^{\mathrm{o} \text {,bulk }}\left(T, p^{\mathrm{o}}\right)-R T \ln p_{\left(\mathrm{O}_{2}\right) \text {,np }} \\
& =R T \ln p_{\left(\mathrm{O}_{2}\right) \text {,bulk }}-R T \ln p_{\left(\mathrm{O}_{2}\right) \text {,np }} \\
& \Delta_{\mathrm{r}} G^{\mathrm{surf}}\left(T, p_{(\mathrm{g})}\right)=\frac{2 V_{\mathrm{m}\left(\mathrm{SnO}_{2}\right)} \gamma_{\left(\mathrm{SnO}_{2}\right)}}{r_{\left(\mathrm{SnO}_{2}\right)}}-\frac{2 V_{\mathrm{m}(\mathrm{Sn})} \gamma_{(\mathrm{Sn})}}{r_{(\mathrm{Sn})}}
\end{aligned}
$$

If the stoichiometric amounts of $\mathrm{Sn}$ and $\mathrm{SnO}_{2}$ are considered, then

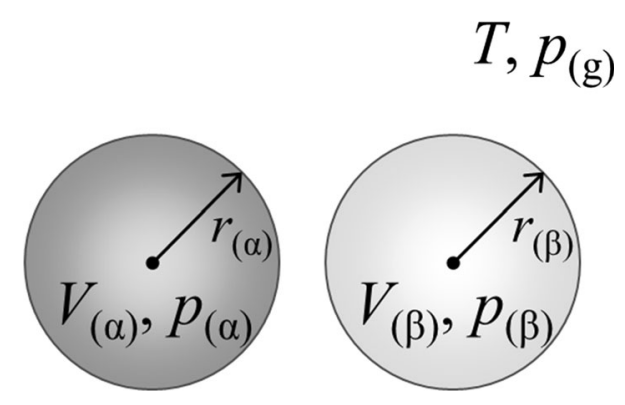

Fig. 2 Spatial configuration of the two single-component particles system $\mathrm{Sn}-\mathrm{O}\left((\alpha)=\mathrm{Sn}(\mathrm{s}, 1),(\beta)=\mathrm{SnO}_{x}(\mathrm{~s})\right)$
Table 2 Basic physicochemical data for tin

\begin{tabular}{llc}
\hline Properties & \multicolumn{1}{c}{ Value } & References \\
\hline Temperature of fusion $T_{(\mathrm{Sn}, \mathrm{s})}^{\mathrm{F}}(\mathrm{K})$ & 505.1 & 24 \\
Enthalpy of fusion $\Delta H_{\mathrm{m}(\mathrm{Sn}, \mathrm{s})}^{\mathrm{F}}\left(\mathrm{J} \mathrm{mol}{ }^{-1}\right)$ & 7029.12 & 24 \\
Entropy of fusion $\Delta S_{\mathrm{m}(\mathrm{Sn}, \mathrm{s})}^{\mathrm{F}}\left(\mathrm{J} \mathrm{K}^{-1} \mathrm{~mol}^{-1}\right)$ & 13.916 & 24 \\
Molar volume of solid $V_{\mathrm{m}(\mathrm{Sn}, \mathrm{s})}$ at $T^{\mathrm{F}}\left(\mathrm{m}^{3} \mathrm{~mol}^{-1}\right)$ & $16.51 \times 10^{-6}$ & 25 \\
Molar volume of liquid $V_{\mathrm{m}(\mathrm{Sn}, \mathrm{l})}$ at $T^{\mathrm{F}}\left(\mathrm{m}^{3} \mathrm{~mol}^{-1}\right)$ & $16.87 \times 10^{-6}$ & 26 \\
Molar volume differences $\Delta V_{\mathrm{m}(\mathrm{Sn})}^{\mathrm{F}}$ at $T^{\mathrm{F}}\left(\mathrm{m}^{3} \mathrm{~mol}^{-1}\right)$ & $0.36 \times 10^{-6}$ & \\
Surface energy of solid $\gamma_{(\mathrm{Sn}, \mathrm{sg})}\left(\mathrm{mJ} \mathrm{m}^{-2}\right)$ & $660-0.5 \times\left(T-T^{\mathrm{F}}\right)$ & 27 \\
Surface energy of liquid $\gamma_{(\mathrm{Sn}, \mathrm{lg})}\left(\mathrm{mJ} \mathrm{m} \mathrm{m}^{-2}\right)$ & $588-0.124 \times\left(T-T^{\mathrm{F}}\right)$ & 27 \\
Interfacial energy solid/liquid $\gamma_{(\mathrm{Sn}, \mathrm{sl})}\left(\mathrm{mJ} \mathrm{m}^{-2}\right)$ & 66.0 & 28 \\
\hline
\end{tabular}




$$
\begin{gathered}
\frac{n_{\left(\mathrm{SnO}_{2}\right)}}{n_{(\mathrm{Sn})}}=\frac{r_{\left(\mathrm{SnO}_{2}\right)}^{3}}{V_{\mathrm{m}\left(\mathrm{SnO}_{2}\right)}} \frac{V_{\mathrm{m}(\mathrm{Sn})}}{r_{\mathrm{Sn}}^{3}} \Rightarrow \\
r_{\left(\mathrm{SnO}_{2}\right)}=r_{(\mathrm{Sn})}\left(\frac{V_{\mathrm{m}\left(\mathrm{SnO}_{2}\right)}}{V_{\mathrm{m}(\mathrm{Sn})}}\right)^{1 / 3}
\end{gathered}
$$

Equation 4 can be used for substituting $r_{(\mathrm{SnO} 2)}$ into the equilibrium relation resulting from $\mathrm{Eq} 1$ to 3

$R T \ln \frac{p_{\left(\mathrm{O}_{2}\right), \mathrm{np}}}{p_{\left(\mathrm{O}_{2}\right), \text { bulk }}}=\frac{2 V_{\mathrm{m}\left(\mathrm{SnO}_{2}\right)} \gamma_{\left(\mathrm{SnO}_{2}\right)}}{r_{\left(\mathrm{SnO}_{2}\right)}}-\frac{2 V_{\mathrm{m}(\mathrm{Sn})} \gamma_{(\mathrm{Sn})}}{r_{(\mathrm{Sn})}}$

which represents an implicit function of temperature, oxygen partial pressure and tin nanoparticle size, $F(T$, $\left.p_{(\mathrm{O} 2), \mathrm{np}}, r_{(\mathrm{Sn})}\right)=0$. It is thus possible to calculate the dependence of $p_{(\mathrm{O} 2)}$ on $r_{(\mathrm{Sn})}$ at given temperature or the dependence of $T$ on $r_{(\mathrm{Sn})}$ at given oxygen pressure. Similar calculations can be performed for $\mathrm{Sn}-\mathrm{SnO}$ and $\mathrm{Sn}-\mathrm{Sn}_{3} \mathrm{O}_{4}$ equilibria.

Using this topology it is convenient to introduce the standard chemical potential of a single-component nanoparticle as

$$
\begin{aligned}
\mu_{i}^{\mathrm{o}, \mathrm{np}}\left(T, p^{\mathrm{o}}\right) & =\mu_{i}^{\mathrm{o}, \text { bulk }}\left(T, p^{\mathrm{o}}\right)+\mu_{i}^{\text {surf }}\left(T, p^{\mathrm{o}}\right) \\
& =G_{\mathrm{m}, i}^{\mathrm{o}, \text { bulk }}\left(T, p^{\mathrm{o}}\right)+\frac{2 V_{\mathrm{m}, i} \gamma_{i}}{r_{i}}
\end{aligned}
$$

At the temperature of tin fusion, $505.1 \mathrm{~K}$, the surface contributions for tin are: $21.787 / r(\mathrm{~nm})(\mathrm{kJ} / \mathrm{mol})$ for solid and $19.841 / r(\mathrm{~nm})(\mathrm{kJ} / \mathrm{mol})$ for liquid $\mathrm{Sn}$. Temperature dependences of the molar volumes and the surface energies were neglected in the following calculations.

The molar volumes, surface energies and surface contribution for tin oxides are summarized in Table 3. Surface energy is the crucial quantity for the surface contribution to the Gibbs energy of nanoparticles. In the case of $\mathrm{SnO}_{2}$, the value $\gamma_{(\mathrm{SnO} 2, \mathrm{sg})}=1200 \mathrm{~mJ} \mathrm{~m}^{-2[33]}$ was chosen. This value based on adsorption calorimetry measurements is markedly lower than $1720 \mathrm{~mJ} \mathrm{~m}^{-2}$ as previously obtained at the same laboratory using a combination of high-temperature oxide melt solution calorimetry and water adsorption calorimetry. ${ }^{[34]}$ On the other hand ab initio calculated values for $\mathrm{SnO}_{2}$ /vacuum interface for various $(h k l)$ surface planes give mean values $1261 \mathrm{~mJ} \mathrm{~m}^{-2},{ }^{[35]}$ $1438 \mathrm{~mJ} \mathrm{~m}^{-2}$, [36] $1407 \mathrm{~mJ} \mathrm{~m}^{-2}$. [37] These mean values were calculated according to the expression ${ }^{[38]}$

$\bar{\gamma}=\frac{n}{\sum_{(h k l)} \frac{1}{\gamma_{(h k l)}}}$

where $n$ means the number of $(h k l)$ surface planes for which $\gamma_{(h k l)}$ is calculated. Only one calculated value $\gamma_{(\mathrm{SnO}, \mathrm{sg})}=392 \mathrm{~mJ} \mathrm{~m}^{-2[37]}$ is available in literature for $\mathrm{SnO}$ surface. As in the case of $\mathrm{SnO}_{2}$ this mean value was obtained using ab initio $\gamma_{(h k l)}$ values according to Eq 7. Due to the lack or the complete absence of surface energy data for $\mathrm{SnO}$ and $\mathrm{Sn}_{3} \mathrm{O}_{4}$ we performed DFT calculations for slabs consisting of six and four unit cells stacked along [001] and [010] directions, respectively, with a $15 \AA$ thick vacuum region inserted between the slabs. The calculations were carried out using all electron full potential method as implemented in WIEN2k program (APW + lo basis set, GGA-PBE96 functional, $R_{\mathrm{MT}} * K_{\max }$ in the range $7.5-8$, typical k-mesh sampling density $\left.0.8 \mathrm{~nm}^{3}\right) .{ }^{[39]}$ As expected, the resulting surface energy values (see Table 3 ) are much lower compared to rutile structure of $\mathrm{SnO}_{2}$ due to the layered character imposing a relatively weak cohesion between the layers in both $\mathrm{SnO}$ and $\mathrm{Sn}_{3} \mathrm{O}_{4}$.

Using Eq 5 in the form

$\log \frac{p_{\left(\mathrm{O}_{2}\right), \mathrm{np}}}{p_{\left(\mathrm{O}_{2}\right), \text { bulk }}}=\frac{1}{R T \ln 10}\left(\frac{2 V_{\mathrm{m}\left(\mathrm{SnO}_{2}\right)} \gamma_{\left(\mathrm{SnO}_{2}\right)}}{r_{\left(\mathrm{SnO}_{2}\right)}}-\frac{2 V_{\mathrm{m}(\mathrm{Sn}, \mathrm{l})} \gamma_{(\mathrm{Sn}, \mathrm{l})}}{r_{(\mathrm{Sn}, \mathrm{l})}}\right)$

the ratio of $\mathrm{O}_{2}$ equilibrium pressure in $\mathrm{Sn}(\mathrm{l})-\mathrm{SnO}_{2}(\mathrm{~s})-\mathrm{O}_{2}$ (g) nano-system and bulk-system as a function of temperature for tin nanoparticles of radius 2.5, 5, 10 and $20 \mathrm{~nm}$ was calculated. As the surface term for solid $\mathrm{SnO}_{2}$ is greater than that for liquid tin, the decrease of nanoparticle size brings about an increase of this ratio (Fig. 3).

Similar calculations were performed for reaction 1.5 $\mathrm{Sn}(\mathrm{l})+\mathrm{O}_{2}(\mathrm{~g})=0.5 \mathrm{Sn}_{3} \mathrm{O}_{4}(\mathrm{~s})$ using $\mathrm{Eq} 9$

\begin{tabular}{|c|c|c|c|}
\hline Oxide & Properties & Value & References \\
\hline \multirow[t]{3}{*}{$\mathrm{SnO}$} & Molar volume $V_{\mathrm{m}(\mathrm{SnO}, \mathrm{s})}$ at $298 \mathrm{~K}_{\left(\mathrm{m}^{3} \mathrm{~mol}^{-1}\right)}$ & $21.03 \times 10^{-6}$ & 40 \\
\hline & Surface energy $\gamma_{(\mathrm{SnO}, \mathrm{sg})}$ at $298 \mathrm{~K}\left(\mathrm{~mJ} \mathrm{~m}^{-2}\right)$ & 216 & This work \\
\hline & $2 V_{\mathrm{m}(\mathrm{SnO}, \mathrm{s})} \gamma_{(\mathrm{SnO}, \mathrm{sg})}$ at $298 \mathrm{~K}\left(\mathrm{~nm} \mathrm{~kJ} \mathrm{~mol}^{-1}\right)$ & 9.085 & \\
\hline \multirow[t]{3}{*}{$\mathrm{Sn}_{3} \mathrm{O}_{4}$} & Molar volume $V_{\mathrm{m}(\mathrm{Sn} 3 \mathrm{O} 4, \mathrm{~s})}$ at $298 \mathrm{~K}\left(\mathrm{~m}^{3} \mathrm{~mol}^{-1}\right)$ & $79.70 \times 10^{-6}$ & This work \\
\hline & Surface energy $\gamma_{(\mathrm{Sn} 3 \mathrm{O} 4, \mathrm{sg})}$ at $298 \mathrm{~K}\left(\mathrm{~mJ} \mathrm{~m}^{-2}\right)$ & 23.6 & This work \\
\hline & $2 V_{\mathrm{m}(\mathrm{Sn} 3 \mathrm{O} 4, \mathrm{~s})} \gamma_{(\mathrm{Sn} 3 \mathrm{O} 4, \mathrm{sg})}$ at $298 \mathrm{~K}\left(\mathrm{~nm} \mathrm{~kJ} \mathrm{~mol}^{-1}\right)$ & 3.761 & This work \\
\hline \multirow[t]{3}{*}{$\mathrm{SnO}_{2}$} & Molar volume $V_{\mathrm{m}(\mathrm{SnO} 2, \mathrm{~s})}$ at $298 \mathrm{~K}\left(\mathrm{~m}^{3} \mathrm{~mol}^{-1}\right)$ & $21.63 \times 10^{-6}$ & 41 \\
\hline & Surface energy $\gamma_{(\mathrm{SnO} 2, \mathrm{sg})}$ at $298 \mathrm{~K}\left(\mathrm{~mJ} \mathrm{~m}^{-2}\right)$ & 1200 & 33 \\
\hline & $2 V_{\mathrm{m}(\mathrm{SnO} 2, \mathrm{~s})} \gamma_{(\mathrm{SnO} 2, \mathrm{sg})}$ at $298 \mathrm{~K}\left(\mathrm{~nm} \mathrm{~kJ} \mathrm{~mol}^{-1}\right)$ & 51.912 & \\
\hline
\end{tabular}

Table 3 Basic

physicochemical data for solid tin oxides 


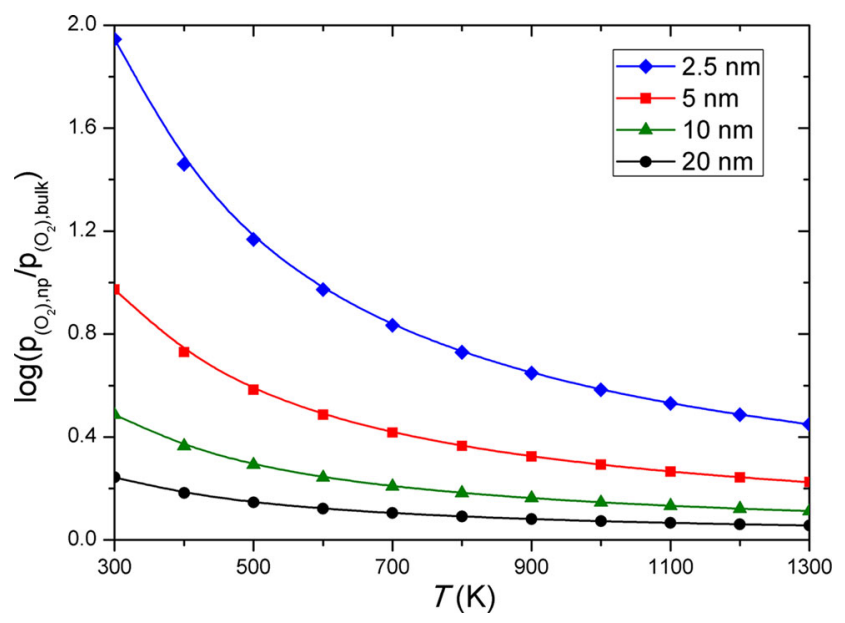

Fig. 3 The ratio of $\mathrm{O}_{2}$ equilibrium pressure in $\mathrm{Sn}(\mathrm{l})-\mathrm{SnO}_{2}(\mathrm{~s})-$ $\mathrm{O}_{2}(\mathrm{~g})$ nano-system and bulk-system as a function of temperature $\left(r_{(\mathrm{Sn})}=2.5,5,10\right.$ and $\left.20 \mathrm{~nm}\right)$

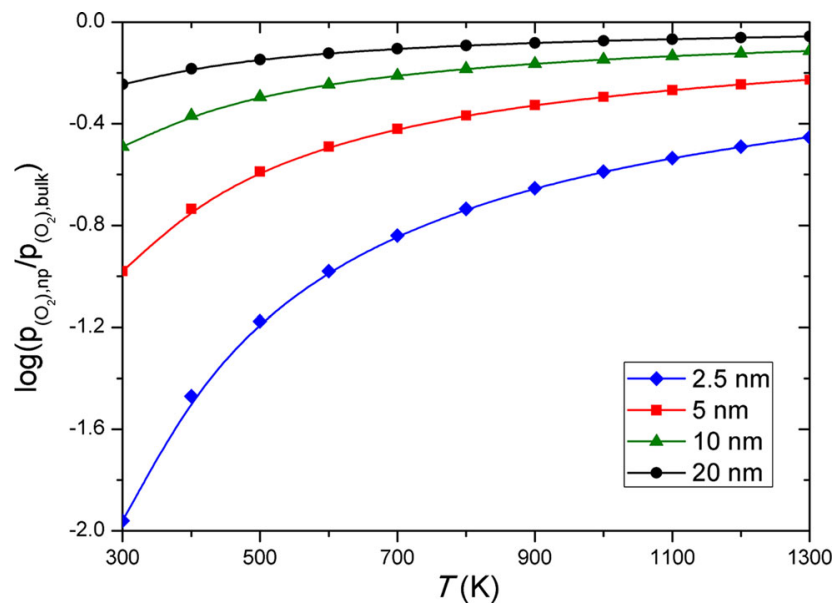

Fig. 4 The ratio of $\mathrm{O}_{2}$ equilibrium pressure in $\mathrm{Sn}(\mathrm{l})-\mathrm{Sn}_{3} \mathrm{O}_{4}(\mathrm{~s})$ $\mathrm{O}_{2}(\mathrm{~g})$ nano-system and bulk-system as a function of temperature $\left(r_{(\mathrm{Sn})}=2.5,5,10\right.$ and $\left.20 \mathrm{~nm}\right)$

$\log \frac{p_{\left(\mathrm{O}_{2}\right), \mathrm{np}}}{p_{\left(\mathrm{O}_{2}\right), \text { bulk }}}=\frac{1}{R T \ln 10}\left(\frac{V_{\mathrm{m}\left(\mathrm{Sn}_{3} \mathrm{O}_{4}\right)} \gamma_{\left(\mathrm{Sn}_{3} \mathrm{O}_{4}\right)}}{r_{\left(\mathrm{Sn}_{3} \mathrm{O}_{4}\right)}}-\frac{3 V_{\mathrm{m}(\mathrm{Sn}, \mathrm{l})} \gamma_{(\mathrm{Sn}, \mathrm{l})}}{r_{(\mathrm{Sn}, \mathrm{l})}}\right)$

Since the surface contributions for solid $\mathrm{Sn}_{3} \mathrm{O}_{4}$ are smaller than that for liquid tin, we observe an opposite trend in this case, namely a decrease of the oxygen pressure ratio with a decrease of nanoparticle size (Fig. 4).

Using the surface terms defined by $2 V_{\mathrm{m}} \gamma_{\mathrm{sg}}$ values given in Table 3 we can calculate the Sn-O phase diagram for a selected nanoparticle size. The calculated phase diagram presented in Fig. 5 for tin oxides nanoparticles whose sizes are deduced from solid tin nanoparticles of radius $5 \mathrm{~nm}$ exhibits notable differences compared to the bulk version. Indeed, the $\mathrm{SnO}$ and $\mathrm{Sn}_{3} \mathrm{O}_{4}$ stability is substantially enhanced at the expense of $\mathrm{SnO}_{2}$ due to the size effect (significantly larger surface energy of $\mathrm{SnO}_{2}$ ). Furthermore, there is only one invariant point in the temperature range $300-800 \mathrm{~K}$, namely $\mathrm{Sn}(\mathrm{s})-\mathrm{SnO}(\mathrm{s})-\mathrm{Sn}_{3} \mathrm{O}_{4}(\mathrm{~s})$ at $T=460 \mathrm{~K}$ and $p\left(\mathrm{O}_{2}\right) / p^{\circ}=4.6 \times 10^{-58}$.

\subsection{Core-Shell Topology}

According to the most experimental findings, the oxidation of Sn nanoparticles leads to a core-shell geometry. This situation is depicted in Fig. 6. The equilibrium condition for the reaction $\mathrm{Sn}(\mathrm{l})+\mathrm{O}_{2}(\mathrm{~g})=\mathrm{SnO}_{2}(\mathrm{~s})$ is derived in "Appendix" (Eq 23, 27, 29, 30 and 31). Using a material balance $\left(r_{0}=r_{(\mathrm{Sn}, 1, \mathrm{np})}, r=r_{(\mathrm{Sn}, 1, \mathrm{core})}\right)$ :

$$
\begin{aligned}
n_{\mathrm{SnO}_{2}} & =\frac{4 \pi}{3 V_{\mathrm{m}\left(\mathrm{SnO}_{2}\right)}}\left[(r+\delta)^{3}-r^{3}\right]=n_{\mathrm{Sn}}^{\mathrm{o}}-n_{\mathrm{Sn}} \\
& =\frac{4 \pi}{3 V_{\mathrm{m}(\mathrm{Sn})}}\left(r_{0}^{3}-r^{3}\right)
\end{aligned}
$$

we obtain for the $\mathrm{SnO}_{2}$ shell thickness

$\delta=\left[\frac{V_{\mathrm{m}\left(\mathrm{SnO}_{2}\right)}}{V_{\mathrm{m}(\mathrm{Sn})}} r_{0}^{3}+\left(1-\frac{V_{\mathrm{m}\left(\mathrm{SnO}_{2}\right)}}{V_{\mathrm{m}(\mathrm{Sn})}}\right) r^{3}\right]^{1 / 3}-r$

Similarly to $\mathrm{Eq} 1, \Delta_{\mathrm{r}} G^{\mathrm{np}}\left(T, p_{(\mathrm{O} 2) \mathrm{np}}\right)=0$ at equilibrium and

$$
\begin{aligned}
R T \ln \frac{p_{\left(\mathrm{O}_{2}\right), \mathrm{np}}}{p_{\left(\mathrm{O}_{2}\right), \mathrm{bulk}}}= & (1+x)\left(\frac{2 \gamma_{\left(\mathrm{SnO}_{2}, \mathrm{~s}\right)} V_{\mathrm{m}\left(\mathrm{SnO}_{2}, \mathrm{~s}\right)}}{r+\delta}-\frac{2 \gamma_{(\mathrm{Sn}, \mathrm{l})} V_{\mathrm{m}(\mathrm{Sn}, \mathrm{l})}}{r_{0}}\right) \\
& +x \frac{2 \gamma_{\left(\mathrm{Sn} / \mathrm{SnO}_{2}\right)} V_{\mathrm{m}(\mathrm{Sn}, \mathrm{l})}}{r}
\end{aligned}
$$

Equation 12 represents a relation $F\left(T, p_{(\mathrm{O} 2), \mathrm{np}}, r_{0}, \delta\right)=0$ and it is possible to calculate the dependence of $\delta$ on temperature or oxygen pressure at a given value o $r_{0}$. The $x$ parameter stands for the amount of unoxidized molten tin when $1 \mathrm{~mol}$ of $\mathrm{SnO}_{2}$ is formed as the shell of nanoparticles: $x=n_{(\mathrm{Sn}, 1, \mathrm{core})} /\left(n_{(\mathrm{Sn}, 1, \mathrm{np})}-n_{(\mathrm{Sn}, 1, \mathrm{core})}\right)$, which can be expressed as

$x=\frac{1}{\left(r_{0} / r\right)^{3}-1}$

It should be noted that for $x=0(r \rightarrow 0), \mathrm{Eq} 12$ is identical with the previously introduced Eq 5 with $r+\delta=r_{(\mathrm{SnO} 2, \mathrm{~s})}$ and $r_{0}=r_{(\mathrm{sn})}$.

One more parameter, namely the interfacial energy $\gamma_{(\mathrm{Sn} /}$ $\mathrm{SnO} 2)$ at the liquid tin/solid $\mathrm{SnO}_{2}$ interface, is included in Eq 12. It can be assessed from contact angle of Sn(1) sessile drop on $\mathrm{SnO}_{2}$ (s) substrate measurement, but such a measurement has not been performed yet. Alternatively, it can be calculated from the work of adhesion $W_{\text {ad }}$ for $\operatorname{Sn}(1) /$ $\mathrm{SnO}_{2}(\mathrm{~s})$ interface and the surface energies of $\mathrm{Sn}(1)$ and $\mathrm{SnO}_{2}$ (s) as 
Fig. 5 Phase diagram of the system $\mathrm{Sn}-\mathrm{O}$ at nanoscale (sizes of nanoparticles included into the calculation are derived from $r(\mathrm{Sn}, \mathrm{s})=5 \mathrm{~nm}$ considering the differences in molar volumes: $r(\mathrm{Sn}, 1)=5.04 \mathrm{~nm}$, $r(\mathrm{SnO})=5.42 \mathrm{~nm}$, $r\left(\mathrm{Sn}_{3} \mathrm{O}_{4}\right)=5.86 \mathrm{~nm}$, $\left.r\left(\mathrm{SnO}_{2}\right)=5.47 \mathrm{~nm}\right)$

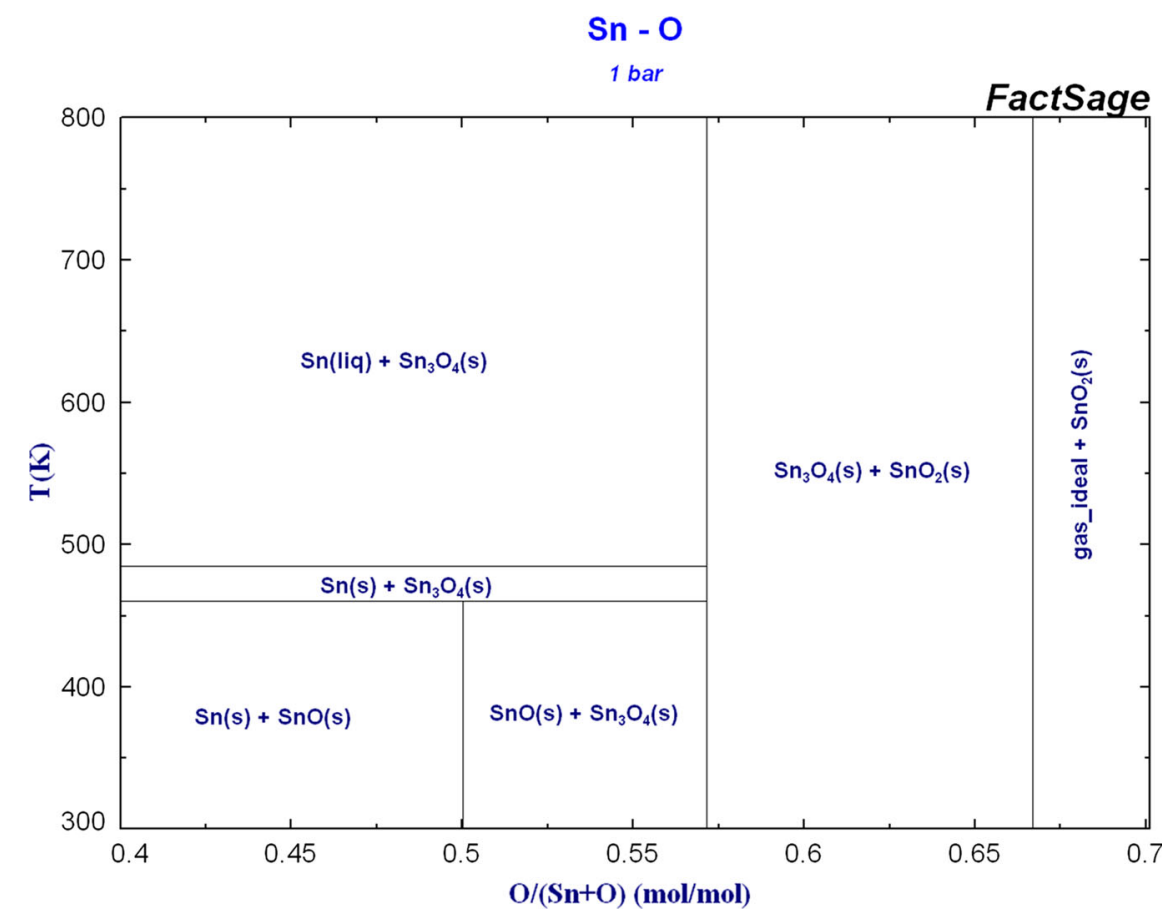

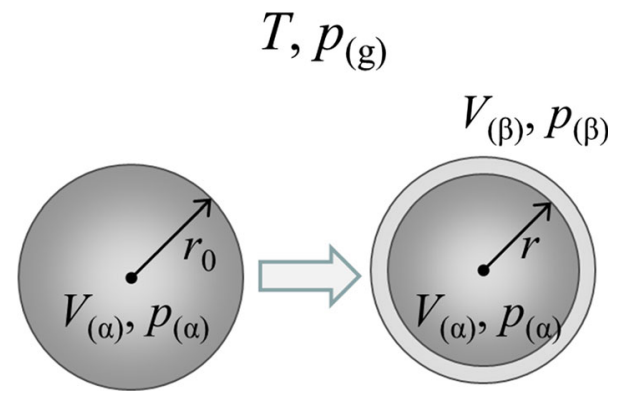

Fig. 6 Spatial configuration of core-shell system $\mathrm{Sn}-\mathrm{O}((\alpha)=\mathrm{Sn}(\mathrm{s}, 1)$, $\left.(\beta)=\mathrm{SnO}_{x}(\mathrm{~s})\right)$

$\gamma_{\left(\mathrm{Sn}, 1 / \mathrm{SnO}_{2}\right)}=\gamma_{\left(\mathrm{SnO}_{2}\right)}+\gamma_{(\mathrm{Sn}, 1)}-W_{\mathrm{ad}}$

Some empirical estimates for the work of adhesion at liquid metal/solid oxide interfaces or just for interfacial energy at liquid metal/solid oxide interfaces have been proposed in literature. ${ }^{[42-46]}$ Here we use a model based on broken bond approximation on the $\mathrm{SnO}_{2}$ interface. While the $\mathrm{Sn}-\mathrm{O}$ bond energy in bulk $\mathrm{SnO}_{2}$ is $229.5 \mathrm{~kJ} \mathrm{~mol}^{-1}$ (obtained from the cohesive energy), the value $E_{\mathrm{b}}(\mathrm{Sn}$ $\mathrm{O})=40.5 \mathrm{~kJ} \mathrm{~mol}^{-1}$ assessed from the surface energy $1200 \mathrm{~mJ} \mathrm{~m}^{-2}$ (Table 3) and the number of broken Sn-O bonds on (001) surface represents only to 18 per cent of the bulk value. This is likely due to relaxation of both the valence electron density and the atomic positions close to the surface. Considering that oxygen atoms on the surface are lacking this portion of energy to saturate their bonding state and there are enough $\mathrm{Sn}$ atoms available for bonding on the $\mathrm{Sn}(1)$ counterpart (1.22 $\mathrm{Sn}$ per $\mathrm{O})$, we can evaluate the adhesion work as $W_{\mathrm{ad}}==600 \mathrm{~mJ} \mathrm{~m}^{-2}$. Let us note that this result is in a very good agreement with the values obtained from models ${ }^{[42]}\left(W_{\mathrm{ad}}==688 \mathrm{~mJ} \mathrm{~m}^{-2}\right)$ based on partial molar enthalpy of oxygen dissolution in liquid tin, $\Delta \bar{H}_{[\mathrm{O}] \mathrm{Sn}(\mathrm{l})}^{\infty}=-182 \mathrm{~kJ} \mathrm{~mol}^{-1} \cdot{ }^{[47]}$ Substituting our value of $W_{\text {ad }}$ into $\mathrm{Eq} 14$ we obtain the corresponding interfacial energy $\gamma_{(\mathrm{Sn} / \mathrm{SnO} 2)}=1190 \mathrm{~mJ} \mathrm{~m}^{-2}$.

Equation 12 was used for the calculation of the surface oxide layer thickness $\delta$ (expressed as $\delta /(r+\delta)$ ) as a function of relative equilibrium $\mathrm{O}_{2}$ pressure (at $T=800 \mathrm{~K}$ ) and temperature (at $p\left(\mathrm{O}_{2}, \mathrm{np}\right) / p\left(\mathrm{O}_{2}\right.$, bulk) $\left.=5\right)$ for a given initial tin particle radius $r_{0}$ (Fig. 7 and 8). Due to the large interfacial energy $\gamma_{(\mathrm{Sn} / \mathrm{SnO} 2)}$ the core-shell structure is not a stable configuration with respect to the complete $\mathrm{SnO}_{2}$ particle and thus the oxidation of tin particles proceeds spontaneously under these $T$ and $p_{(\mathrm{O} 2)}$ conditions. This is imposed by a descending character of the $\delta /(r+\delta)$ versus $\log \left(\mathrm{p}\left(\mathrm{O}_{2}, \mathrm{np} / \mathrm{p}\left(\mathrm{O}_{2}\right.\right.\right.$, bulk $\left.)\right)$ curve, where for a given oxygen pressure the core-shell structure corresponding to a point on the calculated curve has always higher Gibbs energy compared to a single phase $\mathrm{SnO}_{2}$ nanoparticle with $\delta /$ $(r+\delta)=1$. The experimentally observed core-shell structures formed on $\mathrm{Sn}(1)$ oxidation are thus the result of kinetic effects (diffusion of oxygen).

Similar calculations were performed for the shell composed of $\mathrm{Sn}_{3} \mathrm{O}_{4}$ using $\mathrm{Eq} 15$ 


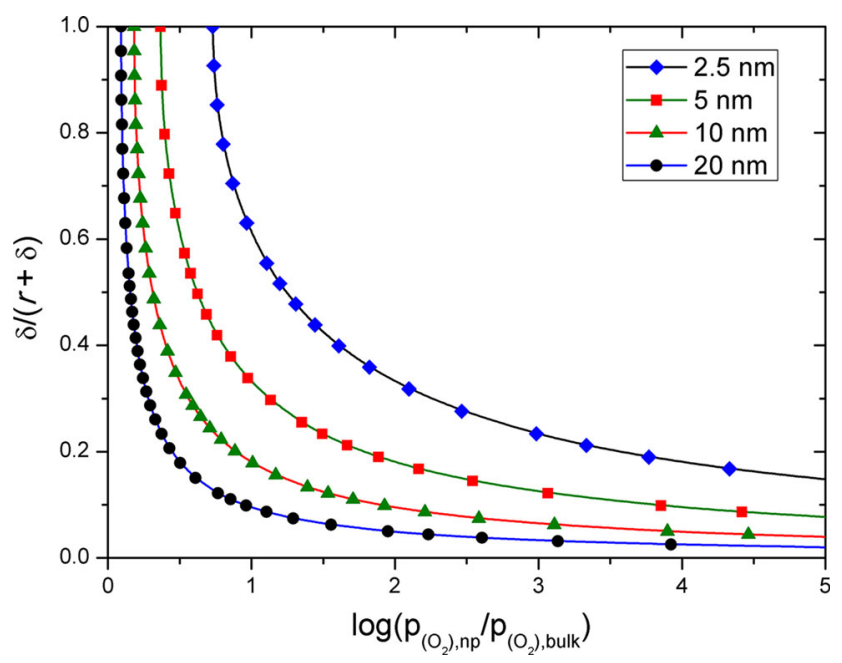

Fig. 7 The dependence of $\mathrm{SnO}_{2}$ surface layer thickness $\delta$ (expressed as $\delta /(r+\delta)$ as a function of relative equilibrium $\mathrm{O}_{2}$ pressure in $\mathrm{Sn}(1)-$ $\mathrm{SnO}_{2}(\mathrm{~s})-\mathrm{O}_{2}(\mathrm{~g})$ nano-system $\left(T=800 \mathrm{~K}, r_{0}=2.5,5,10\right.$ and $\left.20 \mathrm{~nm}\right)$

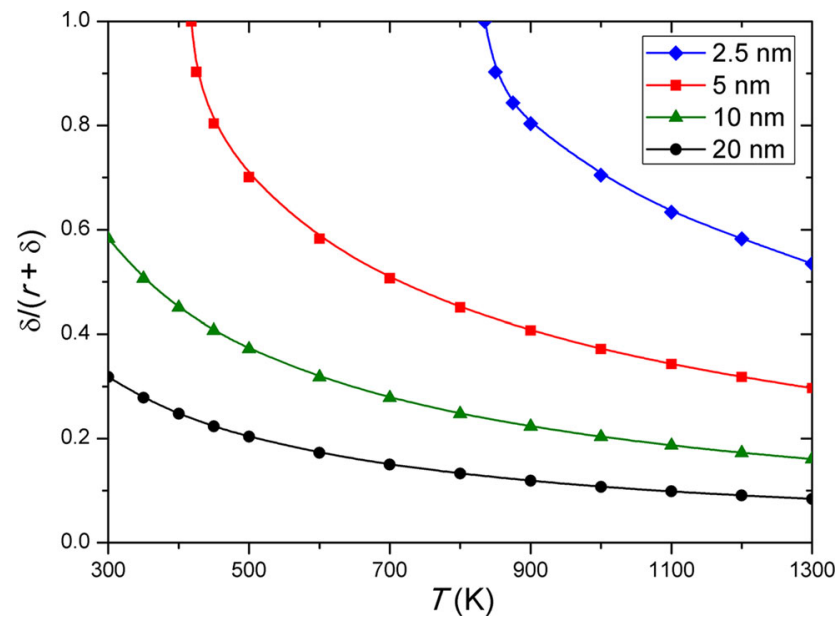

Fig. 8 The dependence of $\mathrm{SnO}_{2}$ surface layer thickness $\delta$ (expressed as $\delta /(r+\delta)$ as a function of temperature in $\mathrm{Sn}(\mathrm{l})-\mathrm{SnO}_{2}(\mathrm{~s})-\mathrm{O}_{2-}$ (g) nano-system $\left(p\left(\mathrm{O}_{2}, \mathrm{np}\right) / p\left(\mathrm{O}_{2}\right.\right.$, bulk $)=5, r_{0}=2.5,5,10$ and $\left.20 \mathrm{~nm}\right)$

$$
\begin{aligned}
\frac{2}{3} R T \ln \frac{p_{\left(\mathrm{O}_{2}\right), \mathrm{np}}}{p_{\left(\mathrm{O}_{2}\right), \mathrm{bulk}}}= & \left(\frac{1}{3}+x\right) \frac{2 \gamma_{\left(\mathrm{Sn}_{3} \mathrm{O}_{4}, \mathrm{~s}\right)} V_{\mathrm{m}\left(\mathrm{Sn}_{3} \mathrm{O}_{4}, \mathrm{~s}\right)}}{r+\delta} \\
& -(1+x) \frac{2 \gamma_{(\mathrm{Sn}, \mathrm{l})} V_{\mathrm{m}(\mathrm{Sn}, \mathrm{l})}}{r_{0}} \\
& +x \frac{2 \gamma_{\left(\mathrm{Sn} / \mathrm{Sn}_{3} \mathrm{O}_{4}\right)} V_{\mathrm{m}(\mathrm{Sn}, \mathrm{l})}}{r}
\end{aligned}
$$

which was derived in the similar way as the relations for $\mathrm{SnO}_{2}$ shell (see "Appendix"). In this case it holds for the surface layer thickness

$\delta=\left[\frac{V_{\mathrm{m}\left(\mathrm{Sn}_{3} \mathrm{O}_{4}\right)}}{3 V_{\mathrm{m}(\mathrm{Sn})}} r_{0}^{3}+\left(1-\frac{V_{\mathrm{m}\left(\mathrm{SnO}_{2}\right)}}{3 V_{\mathrm{m}(\mathrm{Sn})}}\right) r^{3}\right]^{1 / 3}-r$

The contribution of work of adhesion to the interfacial energy is much smaller for the $\mathrm{Sn}(1) / \mathrm{Sn}_{3} \mathrm{O}_{4}(\mathrm{~s})$ interface due

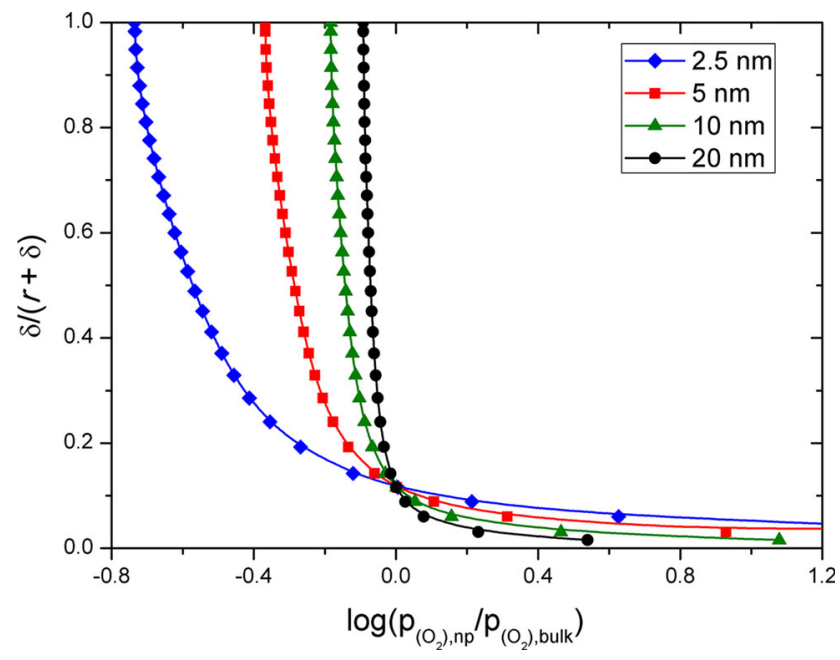

Fig. 9 The dependence of $\mathrm{Sn}_{3} \mathrm{O}_{4}$ surface layer thickness $\delta$ (expressed as $\delta /(r+\delta)$ as a function of relative equilibrium $\mathrm{O}_{2}$ pressure in $\mathrm{Sn}(1)-$ $\mathrm{Sn}_{3} \mathrm{O}_{4}(\mathrm{~s})-\mathrm{O}_{2}(\mathrm{~g})$ nano-system $\left(T=800 \mathrm{~K}, r_{0}=2.5,5,10\right.$ and $\left.20 \mathrm{~nm}\right)$

to very low value of $\gamma_{(\mathrm{Sn} 3 \mathrm{O} 4)}$ (Table 3$)$. As mentioned above, $\mathrm{Sn}_{3} \mathrm{O}_{4}$ exhibits a layered structure which can be derived from rutile- $\mathrm{SnO}_{2}$ by periodically inserting $1 / 3$ of oxygen vacancies arranged in parallel layers. Hence, only weak $\mathrm{Sn}-\mathrm{Sn}$ bonds are broken when an interface is formed at this vacancy-rich plane, and these interactions are assumed to be re-established on the interface with liquid $\mathrm{Sn}$. The respective interfacial energy can be thus put equal to that of liquid tin, $\gamma_{(\mathrm{Sn} / \mathrm{Sn} 3 \mathrm{O} 4)}=\gamma_{(\mathrm{Sn}, \mathrm{lg})}=588 \mathrm{~mJ} \mathrm{~mol}^{-2}$ (Table 2). Using Eq 15 the surface oxide layer thickness $\delta$ (expressed as $\delta /(r+\delta)$ ) as a function of relative equilibrium $\mathrm{O}_{2}$ pressure (at $T=800 \mathrm{~K}$ ) and temperature (at $p\left(\mathrm{O}_{2}, \mathrm{np}\right) / p\left(\mathrm{O}_{2}\right.$, bulk $\left.)=5\right)$ for a given initial tin particle radius $r_{0}$ were calculated (Fig. 9 and 10). The same conclusion regarding the instability of core-shell structure with respect to a single phase $\mathrm{Sn}_{3} \mathrm{O}_{4}$ nanoparticle can be drawn as in the case of $\mathrm{Sn} / \mathrm{SnO}_{2}$ particles but with the difference that $\mathrm{Sn} / \mathrm{Sn}_{3} \mathrm{O}_{4}$ core-shell structures are more stable (closer to the equilibrium state) than the $\mathrm{Sn} / \mathrm{SnO}_{2}$ ones.

\section{Discussion}

Thermodynamic calculations whose results are presented here show a substantial influence of the considered system topology. In the case of single-component nanoparticles the system formed by two independent components (tin and oxygen) has three degree of freedom $\left(T, p_{(\mathrm{O} 2)}, r_{(\mathrm{Sn})}\right)$ and it is possible to formulate three distinct dependences: $T=\mathrm{f}\left(p_{(\mathrm{O} 2)}\right)$ at $\left[r_{(\mathrm{Sn})}\right], \quad T=\mathrm{f}\left(r_{(\mathrm{Sn})}\right)$ at $\left[p_{(\mathrm{O} 2)}\right]$ and $p_{(\mathrm{O} 2)-}$ $=\mathrm{f}\left(r_{(\mathrm{Sn})}\right)$ at $[T]$. Thus, for the constant value of $r_{(\mathrm{Sn})}$, the oxygen pressure $p_{(\mathrm{O} 2)}$ is unambiguously determined by 


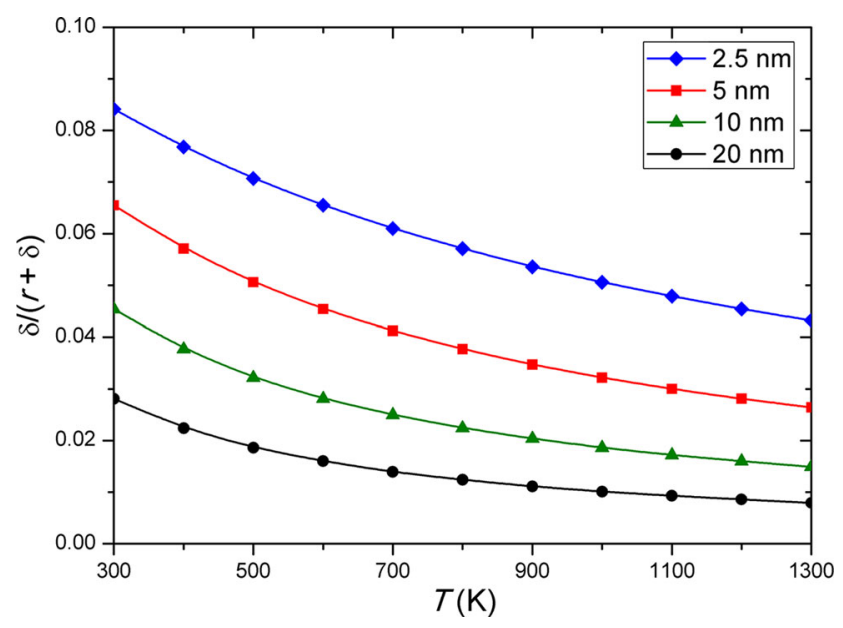

Fig. 10 The dependence of $\mathrm{Sn}_{3} \mathrm{O}_{4}$ surface layer thickness $\delta$ (expressed as $\delta /(r+\delta)$ as a function of temperature in $\mathrm{Sn}(1)-\mathrm{Sn}_{3} \mathrm{O}_{4}(\mathrm{~s})$ $\mathrm{O}_{2}(\mathrm{~g})$ nano-system $\left(p\left(\mathrm{O}_{2}, \mathrm{np}\right) / p\left(\mathrm{O}_{2}\right.\right.$, bulk $)=5, r_{0}=2.5,5,10$ and $20 \mathrm{~nm}$ )

temperature (Fig. 3 and 4). On the other hand, core-shell topology brings four degrees of freedom $\left(T, p_{(\mathrm{O} 2)}, r_{0}, \delta\right)$. For a given size of tin nanoparticles $r_{0}$, the thickness of surface oxide layer $\delta$ is determined by the oxygen pressure (Fig. 7 and 9) at constant temperature or by the temperature (Fig. 8 and 10) at constant oxygen pressure. Our results, which show the instability of core-shell structure, are perhaps surprising. Using the core-shell model Vegh and Kaptay ${ }^{[29]}$ have shown that in the case of lead melting, a core solid and a liquid shell is found in a finite temperature range below the macroscopic melting point. It is a consequence of the simple relation $\gamma_{(\mathrm{Pb}, \mathrm{sg})}>\gamma_{(\mathrm{Pb}, \mathrm{sl})}$ $+\gamma_{(\mathrm{Pb}, \mathrm{lg})}$. In analogy, if the relation $\gamma_{(\mathrm{Me})}>\gamma_{(\mathrm{Me} / \mathrm{MeO} x)}$ $+\gamma_{(\mathrm{MeO} x)}$ was satisfied, a core-shell structure might be stable. But it is not the case for many of the liquid metal/solid oxide interfaces including our system under study. By contrast, in an opposite process of $\mathrm{SnO}_{2}$ reduction into liquid $\mathrm{Sn}$, the $\mathrm{SnO}_{2}$ core- $\mathrm{Sn}(\mathrm{l})$ shell structure would be stable for a certain range of conditions. Another aspect that should be mentioned is the sensitivity of the calculated results on the input parameters. While thermodynamic data for pure substances are rather reliable, the values of surface/interface energies are inconsistent. Considering two single-component particles $\mathrm{Sn}(\mathrm{l}), r_{(\mathrm{sn})}$ $=2.5 \mathrm{~nm}$, and $\mathrm{SnO}_{2}(\mathrm{~s})$ as an example, the calculated oxygen pressures for $\gamma_{(\mathrm{SnO} 2)}=1720 \mathrm{~mJ} \mathrm{~m}^{-2[31]}$ are $2-28$ times higher than those for $\gamma_{(\mathrm{SnO} 2)}=1200 \mathrm{~mJ} \mathrm{~m}^{-2[30]}$ in the temperature range $1300-300 \mathrm{~K}$. The same applies for the interfacial energy $\gamma_{(\mathrm{Sn} / \mathrm{SnO} 2)}$ within the core-shell topology. Also other approximations considered in the calculations, e.g. spherical shape of nanoparticles and temperature-independent molar volumes and surface/ interface energy, bring some uncertainty in the results. Therefore, the results of these calculations must be understood as semi-quantitative estimate rather than the exact values.

The last issue we would like to mention here is the opposite influence of nanosizing on the stability of $\mathrm{SnO}_{2}$ and $\mathrm{SnO} / \mathrm{Sn}_{3} \mathrm{O}_{4}$ oxides within the two single-component nanoparticles model. It is due to the surface contribution which is higher for $\mathrm{SnO}_{2}(\mathrm{~s})$ than $\mathrm{Sn}(\mathrm{l})$ while lower for $\mathrm{SnO}(\mathrm{s})$ and $\mathrm{Sn}_{3} \mathrm{O}_{4}$ (s) compared to $\mathrm{Sn}(\mathrm{l})$. This situation can explain some experimental findings during oxidation of $\mathrm{Sn}$ nanoparticles, namely an increased stability of $\mathrm{SnO}(\mathrm{s})$ and $\mathrm{Sn}_{3} \mathrm{O}_{4}$ (s) with respect to both liquid tin and solid tin dioxide.

Acknowledgments This work was supported by Czech Science Foundation, Grant No. 17-13161S.

\section{Appendix 1}

Let us consider a closed heterogeneous system at constant $T$ and $V$. It follows for the equilibrium from basic thermodynamics relations

$$
\mathrm{d} F_{\text {syst }}=\sum_{\left[n, T, V^{\text {syst }}\right]} \mathrm{d} F_{(\varphi)}+\sum_{\text {interfaces }} \mathrm{d} F_{(\sigma)}=0,
$$

$F$ is the Helmholtz energy and superscripts $\varphi$ and $\sigma$ stand for coexisting bulk phases and interfaces/surfaces, respectively. Let us now describe the equilibrium in the system in Fig. 2 where the reaction $\mathrm{Sn}(\mathrm{l})+\mathrm{O}_{2}(\mathrm{~g})=\mathrm{SnO}_{2}$ (s) takes place $\left((\alpha)=\mathrm{Sn}(\mathrm{l})\right.$ and $\left.(\beta)=\mathrm{SnO}_{2}(\mathrm{~s})\right)$ in terms of the condition (17). The equilibrium corresponds to coexistence of two single-component particles $\mathrm{Sn}(\mathrm{l})$ and $\mathrm{SnO}_{2}(\mathrm{~s})$ and gaseous oxygen at temperature $T$ and oxygen pressure $p_{(\mathrm{O} 2, \mathrm{~g})}$ :

$$
\begin{aligned}
\mathrm{d} F_{\mathrm{syst}}= & \mathrm{d} F_{(\mathrm{Sn}, \mathrm{l})}^{\text {bulk }}+\mathrm{d} F_{\left(\mathrm{SnO}_{2}, \mathrm{~s}\right)}^{\text {bulk }}+\mathrm{d} F_{\left(\mathrm{O}_{2}, \mathrm{~g}\right)}^{\text {bulk }}+\mathrm{d} F_{(\mathrm{Sn}, \mathrm{l})}^{\text {surf }} \\
& +\mathrm{d} F_{\left(\mathrm{SnO}_{2}, \mathrm{~s}\right)}^{\text {surf }} \\
\mathrm{d} F_{(\mathrm{Sn}, \mathrm{l})}^{\text {bulk }}= & -p_{(\mathrm{Sn}, \mathrm{l})} \mathrm{d} V_{(\mathrm{Sn}, \mathrm{l})}+\mu_{(\mathrm{Sn}, \mathrm{l})}\left(p_{(\mathrm{Sn}, \mathrm{l})}\right) \mathrm{d} n_{(\mathrm{Sn}, \mathrm{l})} \\
\mathrm{d}_{\left(\mathrm{SnO}_{2}, \mathrm{~s}\right)}^{\mathrm{bulk}}= & -p_{\left(\mathrm{SnO}_{2}, \mathrm{~s}\right)} \mathrm{d} V_{\left(\mathrm{SnO}_{2}, \mathrm{~s}\right)} \\
& +\mu_{\left(\mathrm{SnO}_{2}, \mathrm{~s}\right)}\left(p_{\left(\mathrm{SnO}_{2}, \mathrm{~s}\right)}\right) \mathrm{d} n_{\left(\mathrm{SnO}_{2}, \mathrm{~s}\right)} \\
\mathrm{d} F_{\left(\mathrm{O}_{2}, \mathrm{~g}\right)}^{\text {bulk }}= & -p_{\left(\mathrm{O}_{2}, \mathrm{~g}\right)} \mathrm{d} V_{\left(\mathrm{O}_{2}, \mathrm{~g}\right)}+\mu_{\left(\mathrm{O}_{2}, \mathrm{~g}\right)}\left(p_{\left(\mathrm{O}_{2}, \mathrm{~g}\right)}\right) \mathrm{d} n_{\left(\mathrm{O}_{2}, \mathrm{~g}\right)} \\
= & p_{\left(\mathrm{O}_{2}, \mathrm{~g}\right)}\left(\mathrm{d} V_{\left(\mathrm{Sn}_{1}\right)}+\mathrm{d} V_{\left(\mathrm{SnO}_{2}, \mathrm{~s}\right)}\right) \\
& +\mu_{\left(\mathrm{O}_{2}, \mathrm{~g}\right)}\left(p_{\left(\mathrm{O}_{2}, \mathrm{~g}\right)}\right) \mathrm{d} n_{\left(\mathrm{O}_{2}, \mathrm{~g}\right)} \\
&
\end{aligned}
$$

Summation of these bulk contributions yields 


$$
\begin{aligned}
- & \left(p_{(\mathrm{Sn}, \mathrm{l})}-p_{\left(\mathrm{O}_{2}, \mathrm{~g}\right)}\right) \mathrm{d} V_{(\mathrm{Sn}, \mathrm{l})}+\mu_{(\mathrm{Sn}, \mathrm{l})}\left(p_{(\mathrm{Sn}, \mathrm{l})}\right) \mathrm{d} n_{(\mathrm{Sn}, \mathrm{l})} \\
& -\left(p_{\left(\mathrm{SnO}_{2}, \mathrm{~s}\right)}-p_{\left(\mathrm{O}_{2}, \mathrm{~g}\right)}\right) \mathrm{d} V_{\left(\mathrm{SnO}_{2}, \mathrm{~s}\right)}+\mu_{\left(\mathrm{SnO}_{2}, \mathrm{~s}\right)}\left(p_{\left(\mathrm{SnO}_{2}, \mathrm{~s}\right)}\right) \mathrm{d} n_{\left(\mathrm{SnO}_{2}, \mathrm{~s}\right)} \\
& +\mu_{\left(\mathrm{O}_{2}, \mathrm{~g}\right)}\left(p_{\left(\mathrm{O}_{2}, \mathrm{~g}\right)}\right) \mathrm{d} n_{\left(\mathrm{O}_{2}, \mathrm{~g}\right)}
\end{aligned}
$$

Supposing incompressibility of liquid tin and solid oxide (molar volume does not depend on pressure) and applying material balance conditions in the stoichiometric form

$n_{i}=n_{i}^{o}+v_{i} \xi, \quad\left(v_{(\mathrm{Sn}, \mathrm{l})}=-1, v_{(\mathrm{O} 2, \mathrm{~g})}=-1, v_{(\mathrm{SnO} 2, \mathrm{~s})}=1\right)$

one can arrange Eq 22 as

$$
\begin{aligned}
& {\left[\mu_{(\mathrm{Sn}, 1)}\left(p_{(\mathrm{Sn}, \mathrm{l})}\right)-\left(p_{(\mathrm{Sn}, \mathrm{l})}-p_{\left(\mathrm{O}_{2}, \mathrm{~g}\right)}\right) V_{\mathrm{m}(\mathrm{Sn}, \mathrm{l})}\right] \mathrm{d} n_{(\mathrm{Sn}, \mathrm{l})}} \\
& \quad+\left[\mu_{\left(\mathrm{SnO}_{2}, \mathrm{~s}\right)}\left(p_{\left(\mathrm{SnO}_{2}, \mathrm{~s}\right)}\right)-\left(p_{\left(\mathrm{SnO}_{2}, \mathrm{~s}\right)}-p_{\left(\mathrm{O}_{2}, \mathrm{~g}\right)}\right) V_{\mathrm{m}\left(\mathrm{SnO}_{2}, \mathrm{~s}\right)}\right] \mathrm{d} n_{\left(\mathrm{SnO}_{2}, \mathrm{~s}\right)} \\
& \quad+\mu_{\left(\mathrm{O}_{2}, \mathrm{~g}\right)}\left(p_{\left(\mathrm{O}_{2}, \mathrm{~g}\right)}\right) \mathrm{d} n_{\left(\mathrm{O}_{2}, \mathrm{~g}\right)}=\left[v_{(\mathrm{Sn}, \mathrm{l})} \mu_{(\mathrm{Sn}, \mathrm{l})}\left(p_{\left(\mathrm{O}_{2}, \mathrm{~g}\right)}\right)\right. \\
& \left.\quad+v_{\left(\mathrm{SnO}_{2}, \mathrm{~s}\right)} \mu_{\left(\mathrm{SnO}_{2}, \mathrm{~s}\right)}\left(p_{\left(\mathrm{O}_{2}, \mathrm{~g}\right)}\right)+v_{\left(\mathrm{O}_{2}, \mathrm{~g}\right)} \mu_{\left(\mathrm{O}_{2}, \mathrm{~g}\right)}\left(p_{\left(\mathrm{O}_{2}, \mathrm{~g}\right)}\right)\right] \mathrm{d} \xi \\
& \quad=\Delta_{\mathrm{r}} G^{\mathrm{bulk}}\left(p_{\left(\mathrm{O}_{2}, \mathrm{~g}\right)}\right) \mathrm{d} \xi
\end{aligned}
$$

The surface terms in Eq 18 can be expressed as

$$
\begin{aligned}
\mathrm{d} F_{(\mathrm{Sn}, \mathrm{l})}^{\text {surf }} & =\gamma_{(\mathrm{Sn}, \mathrm{l})} \mathrm{d} A_{(\mathrm{Sn}, \mathrm{l})}=\gamma_{(\mathrm{Sn}, \mathrm{l})} \frac{\mathrm{d} A_{(\mathrm{Sn}, \mathrm{l})}}{\mathrm{d} V_{(\mathrm{Sn}, \mathrm{l})}} \frac{\mathrm{d} V_{(\mathrm{Sn}, \mathrm{l})}}{\mathrm{d} n_{(\mathrm{Sn}, \mathrm{l})}} \mathrm{d} n_{(\mathrm{Sn}, \mathrm{l})} \\
& =\gamma_{(\mathrm{Sn}, \mathrm{l})} \frac{2 V_{\mathrm{m}(\mathrm{Sn}, \mathrm{l})}}{r_{(\mathrm{Sn}, \mathrm{l})}} v_{(\mathrm{Sn}, \mathrm{l})} \mathrm{d} \xi
\end{aligned}
$$

$$
\begin{aligned}
\mathrm{d}_{\left(\mathrm{SnO}_{2}, \mathrm{~s}\right)}^{\mathrm{surf}} & =\gamma_{\left(\mathrm{SnO}_{2}, \mathrm{~s}\right)} \mathrm{d} A_{\left(\mathrm{SnO}_{2}, \mathrm{~s}\right)} \\
& =\gamma_{\left(\mathrm{SnO}_{2}, \mathrm{~s}\right)} \frac{\mathrm{d} A_{\left(\mathrm{SnO}_{2}, \mathrm{~s}\right)}}{\mathrm{d} V_{\left(\mathrm{SnO}_{2}, \mathrm{~s}\right)}} \frac{\mathrm{d} V_{\left(\mathrm{SnO}_{2}, \mathrm{~s}\right)}}{\mathrm{d} n_{\left(\mathrm{SnO}_{2}, \mathrm{~s}\right)}} \mathrm{d} n_{\left(\mathrm{SnO}_{2}, \mathrm{~s}\right)} \\
& =\gamma_{\left(\mathrm{SnO}_{2}, \mathrm{~s}\right)} \frac{2 V_{\mathrm{m}\left(\mathrm{SnO}_{2}, \mathrm{~s}\right)}}{r_{\left(\mathrm{SnO}_{2}, \mathrm{~s}\right)}} v_{\left(\mathrm{SnO}_{2}, \mathrm{~s}\right)} \mathrm{d} \xi
\end{aligned}
$$

and the summation gives

$$
\begin{aligned}
& {\left[v_{(\mathrm{Sn}, \mathrm{l})} \frac{2 \gamma_{(\mathrm{Sn}, \mathrm{l})} V_{\mathrm{m}(\mathrm{Sn}, \mathrm{l})}}{r_{(\mathrm{Sn}, \mathrm{l})}}+v_{\left(\mathrm{SnO}_{2}, \mathrm{~s}\right)} \frac{2 \gamma_{\left(\mathrm{SnO}_{2}, \mathrm{~s}\right)} V_{\mathrm{m}\left(\mathrm{SnO}_{2}, \mathrm{~s}\right)}}{r_{\left(\mathrm{SnO}_{2}, \mathrm{~s}\right)}}\right] \mathrm{d} \xi} \\
& =\Delta_{\mathrm{r}} G^{\mathrm{surf}} \mathrm{d} \xi
\end{aligned}
$$

$\mathrm{d} F_{\text {syst }}=0$ at equilibrium thus

$\Delta_{\mathrm{r}} G^{\text {bulk }}\left(p_{\left(\mathrm{O}_{2}, \mathrm{~g}\right)}\right)+\Delta_{\mathrm{r}} G^{\text {surf }}=0$

Somewhat more complicated is the derivation of equilibrium condition in the system in Fig. 6 where the same reaction $\mathrm{Sn}(\mathrm{l})+\mathrm{O}_{2}(\mathrm{~g})=\mathrm{SnO}_{2}(\mathrm{~s})$ takes place $((\alpha)=\mathrm{Sn}(\mathrm{l})$ and $\left.(\beta)=\mathrm{SnO}_{2}(\mathrm{~s})\right)$. The equilibrium corresponds to a coexistence of unoxidized $\mathrm{Sn}(\mathrm{l})$ core and $\mathrm{SnO}_{2}$ (s) shell in gaseous oxygen at temperature $T$ and oxygen pressure $p_{(\mathrm{O} 2, \mathrm{~g})}$. Whereas Eq 19-23 for bulk contribution hold as in the previous case, the surface contribution is qualitatively different. Due to different interfaces of $\mathrm{Sn}(1, \mathrm{np})$ nanoparticle and unoxidized $\mathrm{Sn}(1, \mathrm{core})$ the oxidation reaction should be written as $(1+x) \mathrm{Sn}(1, \mathrm{np})+\mathrm{O}_{2}(\mathrm{~g})=\mathrm{SnO}_{2}(-$ s) $+x \operatorname{Sn}(1$, core $)$ however, the bulk properties of $\mathrm{Sn}(1, \mathrm{np})$ and $x \operatorname{Sn}(1$, core $)$ are the same. Thus the surface contribution should read

$\mathrm{d} F^{\text {surf }}=\mathrm{d} F_{(\mathrm{Sn}, 1, \mathrm{np})}^{\text {surf }}+\mathrm{d} F_{(\mathrm{Sn}, 1, \mathrm{core})}^{\mathrm{surf}}+\mathrm{d} F_{\left(\mathrm{SnO}_{2}, \mathrm{~s}\right)}^{\mathrm{surf}}$

$\mathrm{d} F_{(\text {Sn,l,np })}^{\text {surf }}=\gamma_{(\mathrm{Sn}, 1)} \mathrm{d} A_{(\mathrm{Sn}, 1, \mathrm{np})}$

$$
=\gamma_{(\mathrm{Sn}, \mathrm{l})} \frac{\mathrm{d} A_{(\mathrm{Sn}, \mathrm{ln} \mathrm{np})}}{\mathrm{d} V_{(\mathrm{Sn}, \mathrm{ln})}} \frac{\mathrm{d} V_{(\mathrm{Sn}, 1, \mathrm{np})}}{\mathrm{d} n_{(\mathrm{Sn}, \mathrm{l}, \mathrm{np})}} \mathrm{d} n_{(\mathrm{Sn}, \mathrm{l}, \mathrm{np})}
$$$$
=\gamma_{(\mathrm{Sn}, \mathrm{l})} \frac{2 V_{\mathrm{m}(\mathrm{Sn}, \mathrm{l})}}{r_{(\mathrm{Sn}, 1, \mathrm{np})}} v_{(\mathrm{Sn}, 1, \mathrm{np})} \mathrm{d} \xi
$$

$$
\begin{aligned}
\mathrm{d} F_{(\mathrm{Sn}, 1, \text { core })}^{\text {surf }} & =\gamma_{\left(\mathrm{Sn} / \mathrm{SnO}_{2}\right)} \mathrm{d} A_{(\mathrm{Sn}, 1, \text { core })} \\
& =\gamma_{\left(\mathrm{Sn} / \mathrm{SnO}_{2}\right)} \frac{\mathrm{d} A_{(\text {Sn,l,core })}}{\mathrm{d} V_{(\mathrm{Sn}, 1, \text { core })}} \frac{\mathrm{d} V_{(\text {Sn }, 1, \text { core })}}{\mathrm{d} n_{(\text {Sn }, 1, \text { core })}} \mathrm{d} n_{(\text {Sn }, 1, \text { core })} \\
& =\gamma_{\left(\mathrm{Sn} / \mathrm{SnO}_{2}\right)} \frac{2 V_{\mathrm{m}(\mathrm{Sn}, 1)}}{r_{(\mathrm{Sn}, 1, \text { core })}} v_{(\mathrm{Sn}, 1, \text { core })} \mathrm{d} \xi
\end{aligned}
$$

$$
\begin{aligned}
\mathrm{d} F_{\left(\mathrm{SnO}_{2}, \mathrm{~s}\right)}^{\mathrm{surf}} & =\gamma_{\left(\mathrm{SnO}_{2}, \mathrm{~s}\right)} \mathrm{d} A_{\left(\mathrm{SnO}_{2}, \mathrm{~s}\right)} \\
& =\gamma_{\left(\mathrm{SnO}_{2}, \mathrm{~s}\right)} \frac{\mathrm{d} A_{\left(\mathrm{SnO}_{2}, \mathrm{~s}\right)}}{\mathrm{d} V_{(\text {core } / \text { shell })}} \frac{\mathrm{d} V_{(\text {core } / \text { shell })}}{\mathrm{d} n_{(\text {core } / \text { shell })}} \mathrm{d} n_{(\text {core } / \text { shell })} \\
& \doteq \gamma_{\left(\mathrm{SnO}_{2}, \mathrm{~s}\right)} \frac{2 V_{\mathrm{m}\left(\mathrm{SnO}_{2}, \mathrm{~s}\right)}}{r_{(\mathrm{Sn}, 1, \text { core })}+\delta}\left(v_{\left(\mathrm{SnO}_{2}, \mathrm{~s}\right)}+v_{(\mathrm{Sn}, 1, \text { core })}\right) \mathrm{d} \xi
\end{aligned}
$$

To simplify Eq 31 the difference between molar volumes of $\mathrm{Sn}(\mathrm{l})$ and $\mathrm{SnO}_{2}(\mathrm{~s})$ was neglected in the derivative $\mathrm{d} V_{\text {(core/shell) }} / \mathrm{d} n_{\text {(core/shell) }}$. Since $\quad\left(v_{\text {(Sn,l,np) }}=-(1+x)\right.$, $\left.v_{(\mathrm{SnO}, \mathrm{s})}=1, v_{(\mathrm{Sn}, 1, \mathrm{core})}=x\right)$ the surface contribution has got a form

$$
\begin{aligned}
& {\left[-(1+x) \frac{2 \gamma_{(\mathrm{Sn}, \mathrm{l})} V_{\mathrm{m}(\mathrm{Sn}, \mathrm{l})}}{r_{(\mathrm{Sn}, 1, \mathrm{np})}}+x \frac{2 \gamma_{\left(\mathrm{Sn} / \mathrm{SnO}_{2}\right)} V_{\mathrm{m}(\mathrm{Sn}, \mathrm{l})}}{r_{(\mathrm{Sn}, 1, \mathrm{core})}}\right.} \\
& \left.+(1+x) \frac{\left.2 \gamma_{(\mathrm{SnO}}, \mathrm{s}\right)}{r_{(\mathrm{Sn}, 1, \mathrm{core})}+\delta}\right] \mathrm{d} \xi \\
& =\left[(1+x)\left(\frac{2 \gamma_{\left(\mathrm{SnO}_{2}, \mathrm{~s}\right)} V_{\mathrm{m}\left(\mathrm{SnO}_{2}, \mathrm{~s}\right)}}{r_{(\mathrm{Sn}, \mathrm{l}, \mathrm{core})}+\delta}-\frac{2 \gamma_{(\mathrm{Sn}, \mathrm{l})} V_{\mathrm{m}(\mathrm{Sn}, \mathrm{l})}}{r_{(\mathrm{Sn}, 1, \mathrm{np})}}\right)\right. \\
& \left.+x \frac{2 \gamma_{\left(\mathrm{Sn} / \mathrm{SnO}_{2}\right)} V_{\mathrm{m}(\mathrm{Sn}, \mathrm{l})}}{r_{(\mathrm{Sn}, \mathrm{l}, \text { core })}}\right] \mathrm{d} \xi=\Delta_{\mathrm{r}} G^{\mathrm{surf}} \mathrm{d} \xi
\end{aligned}
$$

Equation 27 is valid and applicable for both topologies, two single-component particles and core-shell model, with the difference in surface term being described by Eq 26 and 32 , respectively. 


\section{Appendix 2}

List of symbols

\begin{tabular}{|c|c|}
\hline$A$ & Surface area \\
\hline$E_{\mathrm{b}}$ & Bond energy \\
\hline$F$ & Helmholtz energy \\
\hline$G$ & Gibbs energy \\
\hline$\Delta_{\mathrm{r}} G$ & $\begin{array}{l}\text { The change of Gibbs energy due to reaction } \\
\text { (reaction Gibbs energy) }\end{array}$ \\
\hline$\Delta_{\mathrm{r}} G^{\mathrm{o}}$ & $\begin{array}{l}\text { The change of standard Gibbs energy due to } \\
\text { reaction (standard reaction Gibbs energy) }\end{array}$ \\
\hline$\Delta \bar{H}_{[\mathrm{O}] \operatorname{Sn}(\mathrm{l})}^{\infty}$ & $\begin{array}{l}\text { The partial molar enthalpy of oxygen } \\
\text { dissolution in liquid tin }\end{array}$ \\
\hline$n_{i}$ & The number of moles of the species $i$ \\
\hline$n_{i}^{o}$ & The initial number of moles of the species $i$ \\
\hline$p$ & Pressure \\
\hline$R$ & The gas constant \\
\hline 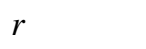 & Radius of spherical nanoparticle \\
\hline$T$ & Temperature \\
\hline$T^{\mathrm{F}}$ & Temperature of fusion \\
\hline$V_{\mathrm{m}}$ & Molar volume \\
\hline$W_{\mathrm{ad}}$ & Work of adhesion \\
\hline$\delta$ & Thickness of surface layer \\
\hline$\gamma$ & Surface or interfacial energy \\
\hline$\mu_{i}$ & The chemical potential of the species $i$ \\
\hline$\mu_{i}^{o}$ & $\begin{array}{l}\text { The standard chemical potential of the species } \\
i \text { (at pressure } p^{\circ}=100 \mathrm{kPa} \text { ) }\end{array}$ \\
\hline$v_{i}$ & The stoichiometric coefficient of the species $i$ \\
\hline$\xi$ & Extent of reaction \\
\hline bulk & Related to bulk properties (bulk contribution) \\
\hline np & Related to nanoparticle \\
\hline surf & $\begin{array}{l}\text { Related to surface properties (surface } \\
\text { contribution) }\end{array}$ \\
\hline
\end{tabular}

\section{References}

1. C.C. Yang and Y.-W. Mai, Thermodynamics at the Nanoscale: A New Approach to the Investigation of Unique Physicochemical Properties of Nanomaterials, Mater. Sci. Eng. R Rep., 2014, 79, p $1-40$

2. W. Qi, Nanoscopic Thermodynamics, Acc. Chem. Res., 2016, 49, p 1587-1595

3. J. Leitner and D. Sedmidubský, Thermodynamic Equilibria in Systems with Nanoparticles, Thermal Physics and Thermal Analysis, Springer, Berlin, 2017, p 385-402

4. A. Navrotsky, C. Ma, K. Lilova, and N. Birkner, Nanophase Transition Metal Oxides Show Large Thermodynamically Driven Shifts in Oxidation-Reduction Equilibria, Science, 2010, 330, p 199-201

5. A. Navrotsky, Nanoscale Effects on Thermodynamics and Phase Equilibria in Oxide Systems, ChemPhysChem, 2011, 12, p 22072215

6. N. Birkner and A. Navrotsky, Thermodynamics of Manganese Oxides: Effects of Particle Size and Hydration on Oxidation-
Reduction Equilibria Among Hausmannite, Bixbyite, and Pyrolusite, Am. Miner., 2012, 97, p 1291-1298

7. S. Cahen, N. David, J. Fiorani, A. Mattre, and M. Vilasi, Thermodynamic Modelling of the O-Sn System, Thermochim. Acta, 2003, 403, p 275-285

8. V. Gurevich, K. Gavrichev, V. Polyakov, R. Clayton, S. Mineev, G. Hu, V. Gorbunov, and L. Golushina, Low-Temperature Heat Capacity of Tin Dioxide: New Standard Data on Thermodynamic Functions, Thermochim. Acta, 2004, 421, p 179-184

9. T.A. White, M.S. Moreno, and P.A. Midgley, Structure Determination of the Intermediate Tin Oxide $\mathrm{Sn}_{3} \mathrm{O}_{4}$ by Precession Electron Diffraction, Z. Kristall., 2010, 225, p 56-66

10. C. Bale, E. Bélisle, P. Chartrand, S. Decterov, G. Eriksson, K. Hack, I.-H. Jung, Y.-B. Kang, J. Melançon, and A. Pelton, FactSage Thermochemical Software and Databases-Recent Developments, Calphad, 2009, 33, p 295-311

11. C.M. Campo, J.E. Rodríguez, and A.E. Ramírez, Thermal Behaviour of Romarchite Phase $\mathrm{SnO}$ in Different Atmospheres: A Hypothesis About the Phase Transformation, Heliyon, 2016, 2, $\mathrm{p}$ e00112

12. H. Giefers, F. Porsch, and G. Wortmann, Kinetics of the Disproportionation of SnO, Solid State Ion., 2005, 176, p 199-207

13. J. Kim, M.Y. Huh, and J.P. Ahn, Effect of particle size on the oxidation behavior of nanophase tin synthesized by inert gas condensation, Solid State Phenomena, 2007, Trans Tech Publications, pp 9-12

14. A. Seko, A. Togo, F. Oba, and I. Tanaka, Structure and Stability of a Homologous Series of Tin Oxides, Phys. Rev. Lett., 2008, 100, p 045702

15. P. Sarker and M.N. Huda, Understanding the Thermodynamic Pathways of SnO-to-SnO ${ }_{x}$ Phase Transition, Comput. Mater. Sci., 2016, 111, p 359-365

16. M.-Y. Huh, S.-H. Kim, J.-P. Ahn, J.-K. Park, and B.-K. Kim, Oxidation of Nanophase tin Particles, Nanostruct. Mater., 1999, 11, p 211-220

17. P. Song and D. Wen, Experimental Investigation of the Oxidation of Tin Nanoparticles, J. Phys. Chem. C, 2009, 113, p 1347013476

18. A. Kolmakov, Y. Zhang, and M. Moskovits, Topotactic Thermal Oxidation of Sn Nanowires: Intermediate Suboxides and CoreShell Metastable Structures, Nano Lett., 2003, 3, p 1125-1129

19. T. Mima, H. Takeuchi, S. Arai, K. Kishita, K. Kuroda, and H. Saka, In Situ Observation of Oxidation of Liquid Droplets of Tin and Melting Behavior of a Tin Particle Covered with a Tin Oxide Layer, Microsc. Res. Tech., 2009, 72, p 223-231

20. E. Sutter, F. Ivars-Barcelo, and P. Sutter, Size-Dependent Room Temperature Oxidation of Tin Particles, Part. Part. Syst. Charact., 2014, 31, p 879-885

21. S. Lai, J. Guo, V. Petrova, G. Ramanath, and L. Allen, SizeDependent Melting Properties of Small Tin Particles: Nanocalorimetric Measurements, Phys. Rev. Lett., 1996, 77, p 99-102

22. H. Jiang, K.-S. Moon, H. Dong, F. Hua, and C. Wong, SizeDependent Melting Properties of Tin Nanoparticles, Chem. Phys. Lett., 2006, 429, p 492-496

23. G. Guisbiers, Review on the Analytical Models Describing Melting at the Nanoscale, J. Nanosci. Lett., 2012, 2, p 8

24. A.T. Dinsdale, SGTE Data for Pure Elements, Calphad, 1991, 15(4), p 317-425

25. M.E. Cavaleri, T.G. Plymate, and J.H. Stout, A Pressure-Volume-Temperature Equation of State for Sn $(\beta)$ by Energy Dispersive $\mathrm{x}$-Ray Diffraction in a Heated Diamond-Anvil Cell, $J$. Phys. Chem. Solids, 1988, 49, p 945-956

26. Z. Moser, W. Gąsior, J. Pstruś, I. Kaban, and W. Hoyer, Thermophysical Properties of Liquid In-Sn Alloys, Int. J. Thermophys., 2009, 30, p 1811-1822 
27. M. Liukkonen, Assessment of Surface Energy Functions for Solid Elements, Helsinki University of Technology, Espoo, 2007

28. Q. Jiang and H. Lu, Size Dependent Interface Energy and Its Applications, Surf. Sci. Rep., 2008, 63, p 427-464

29. A. Vegh and G. Kaptay, Modelling Surface Melting of Macrocrystals and Melting of Nano-crystals for the Case of Perfectly Wetting Liquids in One-Component Systems Using Lead as an Example, Calphad, 2018, 63, p 37-50

30. C. Ma and A. Navrotsky, Thermodynamics of the CoO-ZnO System at Bulk and Nanoscale, Chem. Mater., 2012, 24, p 23112315

31. T. Ivas, A.N. Grundy, E. Povoden-Karadeniz, and L.J. Gauckler, Phase Diagram of $\mathrm{CeO}_{2}-\mathrm{CoO}$ for Nano-sized Powders, Calphad, 2012, 36, p 57-64

32. S.S. Kim, Thermodynamic Modeling of the $\mathrm{CeO}_{2}-\mathrm{CoO}$ Nanophase Diagram, J Alloys Compounds, 2014, 588, p 697-704

33. C.-H. Chang and R.H. Castro, Surface and Grain Boundary Energies of Tin Dioxide at Low and High Temperatures and Effects on Densification Behavior, J. Mater. Res., 2014, 29, p 1034-1046

34. Y. Ma, R.H. Castro, W. Zhou, and A. Navrotsky, Surface Enthalpy and Enthalpy of Water Adsorption of Nanocrystalline Tin Dioxide: Thermodynamic Insight on the Sensing Activity, $J$. Mater. Res., 2011, 26, p 848-853

35. J. Oviedo and M. Gillan, Energetics and Structure of Stoichiometric $\mathrm{SnO}_{2}$ Surfaces Studied by First-Principles Calculations, Surf. Sci., 2000, 463, p 93-101

36. A. Beltran, J. Andrés, E. Longo, and E. Leite, Thermodynamic Argument about $\mathrm{SnO}_{2}$ Nanoribbon Growth, Appl. Phys. Lett., 2003, 83, p 635-637

37. Y. Duan, Electronic Properties and Stabilities of Bulk and LowIndex Surfaces of $\mathrm{SnO}$ in Comparison with $\mathrm{SnO}_{2}$ : A First-Principles Density Functional Approach with an Empirical Correction of van der Waals Interactions, Phys. Rev. B, 2008, 77, p 045332
38. H. Zhang, F. Huang, B. Gilbert, and J.F. Banfield, Molecular Dynamics Simulations, Thermodynamic Analysis, and Experimental Study of Phase Stability of Zinc Sulfide Nanoparticles, $J$. Phys. Chem. B, 2003, 107, p 13051-13060

39. P. Blaha, K. Schwarz, G. Madsen, D. Kvasnicka, J. Luitz, R. Laskowski, F. Tran, L. Marks, WIEN2k: An Augmented Plane Wave + Local Orbitals Program for Calculating Crystal Properties, Techn. Universitat Wien, Austria, 2018, ISBN 3-9501031-1-2

40. H. Giefers, F. Porsch, and G. Wortmann, High-pressure EXAFS and XRD Investigation of Unit Cell Parameters of SnO, Phys. Scr., 2005, 2005, p 538-540

41. S.R. Shieh, A. Kubo, T.S. Duffy, V.B. Prakapenka, and G. Shen, High-pressure Phases in $\mathrm{SnO}_{2}$ to $117 \mathrm{GPa}$, Phys. Rev. B, 2006, 73, p 014105

42. D. Chatain, L. Coudurier, and N. Eustathopoulos, Wetting and Interfacial Bonding in Ionocovalent Oxide-Liquid Metal Systems, Rev. Phys. Appl., 1988, 23, p 1055-1064

43. P. Nikolopoulos, S. Agathopoulos, and A. Tsoga, A Method for the Calculation of Interfacial Energies in $\mathrm{Al}_{2} \mathrm{O}_{3}$ and $\mathrm{ZrO}_{2} / \mathrm{Liq}-$ uid-Metal and liquid-Alloy Systems, J. Mater. Sci., 1994, 29, p 4393-4398

44. G. Kaptay and E. Báder, Ion-Dipole Adhesion Energy Model for Wettability of Oxide Ceramics by Non-reactive Liquid Metals, Trans. JWRI, 2001, 30(SPI), p 55-60

45. H.T. Li, L.F. Chen, X. Yuan, W.Q. Zhang, J.R. Smith, and A.G. Evans, Interfacial Stoichiometry and Adhesion at Metal $/ \alpha-\mathrm{Al}_{2} \mathrm{O}_{3}$ Interfaces, J. Am. Ceram. Soc., 2011, 94, p S154-S159

46. L. Jeurgens, W. Sloof, F. Tichelaar, and E. Mittemeijer, Thermodynamic Stability of Amorphous Oxide Films on Metals: Application to Aluminum Oxide Films on Aluminum Substrates, Phys. Rev. B, 2000, 62, p 4707-4719

47. M.-C. Heuzey and A.D. Pelton, Critical Evaluation and Optimization of the Thermodynamic Properties of Liquid Tin Solutions, Metall. Mater. Trans. B, 1996, 27, p 810-828 